\title{
KELAYAKAN RANCANGAN MEDIA AUDIO VISUAL PERSIAPAN PERSALINAN SEBAGAI MEDIA PROMOSI KESEHATAN PADA IBU HAMIL
}

\section{FEASIBILITY OF AUDIO VISUAL-MEDIA OF CHILDBIRTH PREPARATION AS A HEALTH PROMOTION MEDIA IN PREGNANT WOMEN}

\author{
Euis Tina Haerunisa', Siti Patimah, Herni Kurnia \\ ${ }^{1}$ Politeknik Kesehatan Kemenkes Tasikmalaya, \\ email : euistina.et@gamial.com
}

\begin{abstract}
ABSTRAK
Penurunan AKI dan AKB tidak dapat lepas dari peran pemberdayaan masyarakat, salah satunya dilakukan melalui Program Perencanaan Persalinan dan Pencegahan Komplikasi (P4K). Persiapan persalinan pada ibu hamil dapat diberikan melalui promosi kesehatan. Salah satu media untuk promosi kesehatan yaitu media audio visual, media perantara melalui pandangan dan pendengaran. Tujuan penelitian yaitu menghasilkan produk, mendeskripsikan, merancang serta menguji kelayakan dari media audio visual sebagai media promosi kesehatan. Metode penelitian menggunakan metode Research and development (R\&D), yaitu potensi dan masalah, pengumpulan data, desain produk, validasi desain, revisi desain, uji coba produk, revisi produk, uji coba pemakaian, dan revisi produk. Teknik pengambilan sampel menggunakan purposive sampling, jumlah sampel sebanyak 65 orang ibu hamil untuk uji coba kelompok kecil dan uji coba kelompok besar. Analisa data menggunakan kuantitatif dan kualitatif. Hasil dari penelitian dan pengembangan yaitu media audio visual berbentuk video yang berisi materi tentang persiapan persalinan. Uji validitas yang telah dilakukan ahli media mendapatkan skor 4,56 kategori sangat baik, ahli materi mendapatkan skor 4,68 kategori sangat baik, responden kelompok kecil dan kelompok besar mendapatkan skor 4,4 dan 4,58 kategori sangat baik. Dapat disimpulkan bahwa media audio visual mendapat kategori sangat baik. Penelitian ini dapat dikembangkan lebih lanjut bagaimana efektivitas dari media audio visual.
\end{abstract}

Kata Kunci : Media Audio Visual, Persiapan Persalinan 


\begin{abstract}
The reduction in maternal and child mortality cannot be separated from the role of community empowerment which is done through the implementation of classes for pregnant women and the Birth Planning and Prevention Complications (P4K) Program. Childbirth preparation for pregnant women is to provide health promotion. One effort in providing health promotion is to use the audio-visual media as an intermediary media through sight and hearing. The purpose of this research is to produce products, describe, design and test the feasibility of audiovisual media childbirth preparation as a health promotion media. The method of the research is Research and development (R\&D) that is potential and problems, collection data, product design, design validation, design revision, product test, product revision, trial use, and product revision. The sampling technique is purposive sampling, with a total sample of 65 pregnant women for a small group and large group trials. Analysis of data uses quantitative and qualitative. The results of the research and development are audio-visual media in the form of videos containing material about labor preparation. Validity test that has been done media experts gets a score of 4,56 the excellent category, material experts get sa score of 4,68 the very good category, small group and large group respondents get a score of 4,4 and 4,58 the excellent category. It can be concluded that audio-visual media is included in the excellent category. This research can be further developed how the effectiveness of audio-visual.
\end{abstract}

\title{
Keywords: Audio Visual Media, Childbirth Preparation
}

\section{PENDAHULUAN}

Angka Kematian Ibu (AKI) merupakan salah satu indikator untuk melihat keberhasilan upaya kesehatan ibu. ${ }^{1}$ Angka kematian ibu di Jawa Barat pada tahun 2017 yaitu sebesar 76,03 per 100.000 KH. Pada umumnya kematian ibu terjadi pada saat melahirkan (60,87\%), waktu nifas (30,43\%) dan waktu hamil (8,70\%). Pada tahun 2017 Kabupaten Tasikmalaya berada di urutan ke 5 yaitu dengan jumlah 120,3 per 100.000 kelahiran hidup. $^{2}$

Penurunan kematian ibu dan anak tidak dapat lepas dari peran pemberdayaan masyarakat, yang salah satunya dilakukan melalui pelaksanaan kelas ibu hamil dan Program Perencanaan Persalinan dan Pencegahan Komplikasi (P4K). ${ }^{1}$ Persiapan 
persalinan merupakan persiapan rencana tindakan yang dibuat boleh ibu, anggota keluarga dan bidan. Persiapan ini tidak harus dalam bentuk tertulis, namun dalam bentuk diskusi untuk memastikan bahwa ibu dapat menerima asuhan yang diperlukan. ${ }^{3}$

Hubungan antara ibu hamil dengan persiapan persalinan sangat penting untuk menjamin keselamatan ibu dan bayi baru lahir, dan supaya tidak mengakibatkan adanya keterlambatan, baik secara langsung maupun tidak langsung terutama pada saat ibu mengalami kegawat daruratan. Beberapa cara untuk mempersiapkan persiapan persalinan pada ibu hamil yaitu salah satunya memberikan promosi kesehatan pada ibu hamil. Karena ketersediaan informasi yang akurat dan benar tentang persiapan persalinan diharapkan dapat lebih meningkatkan pengetahuan serta kesiapan ibu dalam menjalani persalinan.

Dalam melakukan promosi kesehatan, dapat menggunakan media atau alat bantu yang merupakan semua sarana atau upaya menampilkan pesan atau informasi yang ingin disampaikan oleh komunikator, baik melalui media cetak, elektronika, dan media luar ruang, sehingga pengetahuan sasaran dapat meningkat dan akhirnya dapat mengubah perilaku ke arah positif terhadap kesehatan. ${ }^{6}$ Salah satu upaya dalam pemberian penyuluhan ataupun promosi kesehatan yaitu dengan menggunakan media audio visual. Media audio visual merupakan media perantara atau penggunaan materi dan penyerapannya melalui pandangan dan pendengaran sehingga membangun kondisi yang dapat membuat seseorang mampu memperoleh pengetahuan, keterampilan atau sikap. ${ }^{7}$

Kelebihan dari media audio visual yaitu dapat menarik perhatian untuk periodeperiode yang singkat dari rangsangan lainnya, sejumlah besar penonton dapat memperoleh informasi dari ahli-ahli atau spesialis, demonstrasi yang sulit bisa dipersiapkan dan direkam sebelumnya, menghemat waktu dan rekaman dapat diputar berulang-ulang, keras lemah suara dapat diatur dan disesuaikan apabila akan disisipi komentar yang akan didengar, bisa mengatur di mana dia akan menghentikan gerakan gambar tersebut, ruangan tidak perlu digelapkan saat penyajiannya. $^{8}$

Hal tersebut sesuai dengan pendapat Lisa Liana, yaitu cara penyajian melalui media audio visual dirasakan lebih menarik daripada menggunakan leaflet, selain itu pendidikan kesehatan dengan menggunakan media audio visual mempunyai 
pengaruh signifikan terhadap perbaikan pengetahuan dan sikap seseorang. ${ }^{9}$ Hasil penelitian Agustin menemukan bahwa penggunaan penyuluhan menggunakan media audio visual lebih besar berpengaruh terhadap tingkat pengetahuan dibandingkan dengan penyuluhan menggunakan media booklet. ${ }^{10}$

Hasil studi pendahuluan di UPT Puskesmas Ciawi, Wawancara dilakukan pada 10 ibu hamil yang memeriksakan kehamilannya di wilayah kerja UPT Puskesmas Ciawi, ditemukan 7 orang ibu hamil yang belum mengetahui persiapan yang harus dilakukan menjelang persalinan, dari beberapa jawaban ibu hamil tersebut mereka hanya terfokus kepada persiapan kebutuhan bayi baru lahir.

Hasil wawancara kepada bidan desa yang ada di wilayah UPT Puskesmas Ciawi, selama melakukan kelas ibu hamil maupun promosi kesehatan kepada ibu hamil, bidan desa selalu menggunakan metode ceramah dengan bantuan media leaflet, lembar balik serta menggunakan power point. Hal tersebut dirasakan masih kurang efektif karena masih banyak kasus khususnya dalam pengambilan keputusan pada saat persalinan yang masih tergantung pada salah satu orang saja, misalnya pada suami. Bidan desa mengatakan belum pernah menggunakan media audio visual dalam melakukan promosi kesehatan, dan bidan desa tertarik menggunakan media tersebut sebagai media promosi kesehatan khususnya tentang persiapan persalinan yang diharapkan dapat lebih efektif karena penyampaiannya yang dianggap lebih menarik.

\section{METODE PENELITIAN}

Jenis penelitian yang digunakan dalam penelitian ini adalah metode penelitian dan pengembangan atau dalam bahasa inggrisnya Research and development. Rancangan media audio visual dirancang melalui beberapa tahapan. Adapun langkah-langkah dari penelitian dan pengembangan menurut Sugiyono (2017), yaitu potensi dan telaah masalah, pengumpulan data, desain produk, validasi desain, uji coba pemakaian, revisi desain, uji coba produk, revisi produk dan produksi masal. ${ }^{22}$ Penelitian ini hanya sampai pada tahap revisi produk karena keterbatasan dana, waktu dan tenaga peneliti. Penelitian ini difokuskan pada kelayakan rancangan media audio visual persiapan persalinan yang dikemas dalam bentuk video.

Populasi dalam penelitian ini adalah ibu hamil yang berjumlah 182 orang, di wilayah kerja UPT Puskesmas Ciawi Kabupaten Tasikmalaya tahun 2019 pada bulan 
November-Desember 2019. Sampel yang digunakan dalam penelitian ini dipilih teknik pengambilan sampel menggunakan purposive sampling. sampel yang dibutuhkan dalam penelitian ini adalah 65 orang ibu hamil untuk uji coba kelompok kecil dan uji coba kelompok besar.

Dalam penelitian ini data yang di ambil menggunakan data primer dengan diberikannya kuesioner untuk validasi dan uji coba produk.

\section{HASIL PENELITIAN DAN PEMBAHASAN}

(1) Potensi masalah dan telaah kebutuhan

Masalah yang didapatkan dari hasil wawancara pada 10 ibu hamil yang memeriksakan kehamilannya, ditemukan 7 orang ibu hamil yang belum mengetahui persiapan yang harus dilakukan menjelang persalinan, dari beberapa jawaban ibu hamil tersebut mereka hanya terfokus kepada persiapan kebutuhan bayi baru lahir.

Hasil wawancara kepada bidan desa, bahwa masih banyak kasus khususnya dalam pengambilan keputusan pada saat persalinan yang masih tergantung pada salah satu orang saja, misalnya pada suami. Selama melakukan kelas ibu hamil maupun promosi kesehatan kepada ibu hamil khususnya mengenai persiapan persalinan, bidan desa menggunakan metode ceramah dengan bantuan media leaflet, lembar balik serta menggunakan power point. Bidan desa belum pernah menggunakan dan mempunyai media audio visual dalam melakukan promosi kesehatan khususnya tentang persiapan persalinan.

(2) Mengumpulkan data

Kegiatan dalam tahap ini dilakukan dengan cara melakukan pengamatan dan wawancara pada ibu hamil yang melakukan pemeriksaan di wilayah kerja UPT Puskesmas Ciawi dan bidan desa di wilayah tersebut. Berdasarkan hasil wawancara dan pengamatan pada ibu hamil dan bidan desa diperoleh informasi mengenai pokok permasalahan terhadap penggunaan media promosi kesehatan serta analisis kebutuhan dikumpulkan sebagai dasar dalam pembuatan rancangan media promosi kesehatan berupa rancangan media audio visual serta untuk menyusun latar belakang dan rumusan masalah penelitian. Kemudian mengumpulkan referensi dan bahan materi dari buku-buku, jurnal-jurnal serta artikel. 
(3) Desain produk

Tahap ini mulai ditetapkan rancangan produk untuk memecahkan masalah yang telah ditemukan pada tahap sebelumnya. Desain penelitian ini, produk yang dirancang berupa media promosi kesehatan yaitu rancangan media audio visual persiapan persalinan untuk ibu hamil.

Penulis membuat design produk berupa flowchart dan story board secara tertulis yang merupakan perencanaan tentang rangkaian gerakan yang akan ditampilkan dalam video sesuai dengan materi, dibuat sendiri oleh penulis dan berkolaborasi dengan konsultan yaitu Taufik Yogaswara, S. Pd, beliau merupakan seorang design grafis yang telah mempunyai banyak pengalaman dan keahlian dibidang tersebut, kemudian membuat rancangan berikut adalah beberapa tahapan dari pengembangan media audio visual persiapan persalinan, yaitu :



Gambar 1 Pengembangan media audio persiapan persalinan menggunakan Adobe After Effects

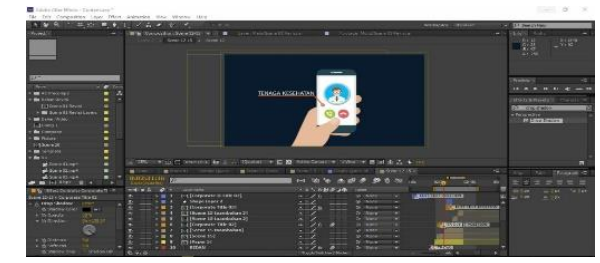

Gambar 2 Pengembangan media audio persiapan persalinan menggunakan Adobe After Effects 


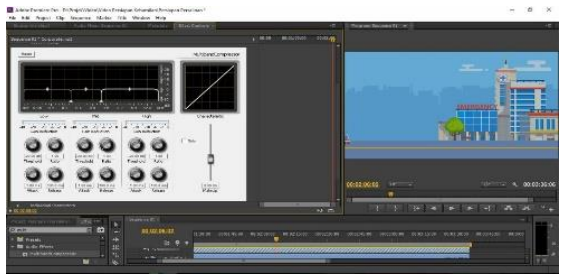

Gambar 3 Pengembangan backsound media audio persiapan persalinan menggunakan Adobe Premiere

(4) Validasi desain

1) Data hasil validasi desain oleh Ahli Media

Aspek yang divalidasi oleh ahli media yaitu Visible, Interesting, Simpel, Useful, Accurate, legitimate, dan Structure (VISUALS) yang diadopsi dari Eka Wahyu $\mathrm{H}$, dkk (2019). ${ }^{27}$ Validasi ahli media dilakukan pada tanggal 28 November 2019 oleh Bapak Eka Wahyu Hidayat, S.T., M.T, di Fakultas Teknik, Universitas Siliwangi.

Tabel 1 Jumlah Akhir Rerata Skor semua Aspek VISUALS oleh Ahli Media

\begin{tabular}{clcl}
\hline No. & $\begin{array}{c}\text { Aspek Yang } \\
\text { Dinilai }\end{array}$ & $\begin{array}{c}\text { Rerata } \\
\text { Skor }\end{array}$ & Kategori \\
\hline 1. & Visible & 4,5 & Sangat Baik \\
\hline 2. & Interesting & 5 & Sangat Baik \\
\hline 3. & Simpel & 3,67 & Baik \\
\hline 4. & Useful & 5 & Sangat Baik \\
\hline 5. & Accurate & 4,28 & Sangat Baik \\
\hline 6. & Legitimate & 4,5 & Sangat Baik \\
\hline 7. & Structure & 5 & Sangat Baik \\
\hline & Jumlah Skor & 31,95 & Sangat Baik \\
\hline & Rerata Skor & 4,56 & \\
& & &
\end{tabular}

Hasil dari tabel di atas, menunjukkan bahwa hasil evaluasi dari aspek VISUALS oleh ahli media terdapat 1 aspek yang mendapatkan nilai 3,67 dan termasuk ke dalam kategori baik yaitu pada aspek simpel, tetapi dari keseluruhan aspek yang telah di nilai oleh ahli media mendapatkan nilai rerata skor 4,56, dimana nilai tersebut termasuk ke dalam kategori sangat baik. 
2) Data hasil validasi desain oleh Ahli materi

Aspek yang divalidasi oleh ahli media yaitu aspek kebenaran, keluasan dan kedalaman materi, aspek bahasa, aspek keterlaksanaan, aspek tampilan video, aspek audio yang diadopsi dari Fuji Laksono(2017) ${ }^{13}$ dan Sholichah, MW (2018) 28

Validasi ahli media dilakukan pada tanggal 02 dan 16 Desember 2019 oleh Ibu Dr. Yati Budiarti, S.ST., M.Keb di Poltekkes Kemenkes Tasikmalaya.

Tabel 2 Jumlah Akhir Rerata Skor semua Aspek oleh Ahli Materi

\begin{tabular}{clcc}
\hline No. & Aspek Yang Dinilai & Rerata Skor & Kategori \\
\hline 1. & $\begin{array}{l}\text { Aspek Kebenaran, } \\
\text { Keluasan dan } \\
\end{array}$ & 2,6 & Cukup Baik \\
& Kedalaman materi & & \\
\hline 2. & Aspek Bahasa & 2 & Tidak Baik \\
\hline 3. & $\begin{array}{l}\text { Aspek } \\
\text { Keterlaksanaan }\end{array}$ & 2,3 & Tidak Baik \\
\hline 4. & $\begin{array}{l}\text { Aspek Tampilan } \\
\text { Video }\end{array}$ & 3 & Cukup Baik \\
\hline 5. & Aspek Audio & 3,67 & Baik \\
\hline & Jumlah Skor & 13,57 & Cukup Baik \\
\hline & Rerata Skor & 2,71 & \\
\hline
\end{tabular}

Hasil dari tabel di atas, menunjukkan hasil evaluasi dari semua aspek oleh ahli materi aspek bahasa 2, keterlaksanaan 2,3 termasuk ke dalam kategori tidak baik, 2 aspek mendapat nilai cukup dan 1 aspek yang mendapatkan nilai baik yaitu pada aspek audio, dengan nilai 3,67. Untuk keseluruhan aspek yang telah di nilai oleh ahli materi mendapatkan nilai rerata skor 2,71, dimana nilai tersebut termasuk ke dalam kategori cukup baik. Dengan hasil nilai akhir yang didapat kategori cukup baik maka perlu dilakukan uji validitas ke 2 oleh ahli materi.

\begin{tabular}{|c|c|c|c|}
\hline No & Aspek Yang Dinilai & $\begin{array}{c}\text { Rerata } \\
\text { Skor }\end{array}$ & Kategori \\
\hline 1. & $\begin{array}{lr}\text { Aspek } & \text { Kebenaran, } \\
\text { Keluasan } & \text { dan }\end{array}$ & 5 & Sangat Baik \\
\hline
\end{tabular}




\begin{tabular}{clcl}
\hline 2. & Aspek Bahasa & 4,5 & Sangat Baik \\
\hline 3. & Aspek Keterlaksanaan & 4,3 & Sangat Baik \\
\hline 4. & Aspek Tampilan Video & 4,6 & Sangat Baik \\
\hline 5. & Aspek Audio & 5 & Sangat Baik \\
\hline & Jumlah Skor & 23,4 & Sangat Baik \\
\cline { 1 - 2 } & Rerata Skor & 4,68 & \\
\end{tabular}

Setelah dilakukan uji validitas ke 2 oleh ahli materi, didapatkan hasil peningkatan dari setiap aspek yang dinilai, hasil dari tabel di atas menunjukkan bahwa hasil jumlah akhir rerata skor dari semua aspek oleh ahli materi pada uji validitas tahap ke 2, yaitu mendapatkan nilai rerata skor 4,68, dimana nilai tersebut termasuk ke dalam kategori sangat baik.

(5) Revisi Produk

1) Ahli media

\section{Tabel 4 Revisi Ahli Media}

\begin{tabular}{|c|c|c|}
\hline No & Revisi & Tindak Lanjut \\
\hline 1. & $\begin{array}{l}\text { Opening video disarankan } \\
\text { didahului dengan kata } \\
\text { mempersembahkan dan } \\
\text { logo almamater supaya } \\
\text { tidak langsung ke titik inti. }\end{array}$ & $\begin{array}{l}\text { Telah dilakukan perbaikan, } \\
\text { opening diawali dengan } \\
\text { gambar logo almamater dan } \\
\text { terdapat } \\
\text { mempersembahkan }\end{array}$ \\
\hline 2. & $\begin{array}{l}\text { Pertimbangan penggunaan } \\
\text { bahasa yang familiar bagi } \\
\text { pengguna }\end{array}$ & $\begin{array}{l}\text { Telah dilakukan perbaikan, } \\
\text { penggunaan bahasa menjadi } \\
\text { lebih mudah untuk dipahami } \\
\text { dan familiar. }\end{array}$ \\
\hline 3. & $\begin{array}{l}\text { Penggunaan suara perlu } \\
\text { dipertimbangkan dengan } \\
\text { suara hasil dubbing }\end{array}$ & $\begin{array}{l}\text { Telah dilakukan perbaikan pada } \\
\text { pengisi suara, yang pertama } \\
\text { menggunakan suara dari } \\
\text { google, kemudian diganti } \\
\text { dengan suara dubbing. }\end{array}$ \\
\hline
\end{tabular}


Asian Research Midwifery and Basic Science Journal e-ISSN:

2) Ahli materi

Tabel 5 Revisi Ahli Materi

\begin{tabular}{|c|c|c|}
\hline No. & Revisi & Tindak Lanjut \\
\hline 1. & $\begin{array}{l}\text { Kartun bidan lebih lucu } \\
\text { dan berwibawa serta } \\
\text { komunikatif }\end{array}$ & $\begin{array}{l}\text { Telah dilakukan perbaikan, } \\
\text { kartun bidan menjadi lebih } \\
\text { berwibawa dengan posisi } \\
\text { berdiri dan komunikatif }\end{array}$ \\
\hline 2. & Materi dibuat lebih ringan & $\begin{array}{l}\text { Telah dilakukan perbaikan, } \\
\text { materi dan bahasa yang } \\
\text { digunakan menjadi lebih ringan }\end{array}$ \\
\hline 3. & $\begin{array}{lr}\text { Kesimpulan, gambar } \\
\text { persiapan yang sudah } \\
\text { matang }\end{array}$ & $\begin{array}{l}\text { Telah dilakukan perbaikan, } \\
\text { terdapat gambar ibu dan suami } \\
\text { siap untuk mempersiapkan } \\
\text { persalinan }\end{array}$ \\
\hline
\end{tabular}

(6) Hasil uji coba produk pada kelompok kecil

Tabel 6 Jumlah Akhir Rerata Skor semua Aspek dari Hasil Uji Coba Produk pada Kelompok Kecil

\begin{tabular}{clccc} 
No. & Aspek Yang Dinilai & Rerata Skor & Kategori \\
\hline 1. & Kualitas Tampilan & 4,45 & & Sangat Baik \\
\hline 2. & Aspek Isi & 4,34 & Sangat Baik \\
\hline & Jumlah Skor & $\mathbf{8 , 7 9}$ & Sangat Baik \\
\cline { 1 - 2 } & Rerata Skor & $\mathbf{4 , 4}$ & \\
\hline
\end{tabular}

Hasil dari tabel di atas, menunjukkan bahwa hasil jumlah akhir rerata skor dari semua aspek oleh responden kelompok kecil yaitu mendapatkan nilai rerata skor 4,4, dimana nilai tersebut termasuk ke dalam kategori sangat baik.

(7) Revisi hasil uji coba produk pada kelompok kecil

Berdasarkan hasil uji coba produk pada kelompok kecil, menunjukkan hasil sangat baik dari setiap aspeknya. Beberapa dari ibu hamil memberikan saran bahwa media audio visual persiapan persalinan sudah bagus. Maka dari itu, dalam tahap uji coba produk dari kelompok kecil tidak ada revisi dan dapat langsung dilanjutkan dengan uji coba pemakaian pada kelompok besar. 
(8) Hasil Uji coba Pemakaian pada kelompok besar

Tabel 7 Jumlah Akhir Rerata Skor semua Aspek dari Hasil Uji Coba Pemakaian pada Kelompok Besar

\begin{tabular}{clcc}
\hline No. & $\begin{array}{c}\text { Aspek Yang } \\
\text { Dinilai }\end{array}$ & Rerata Skor & Kategori \\
\hline 1. & $\begin{array}{l}\text { Kualitas } \\
\text { Tampilan }\end{array}$ & 4,58 & Sangat Baik \\
\cline { 1 - 2 } 2. & Aspek Isi & 4,57 & Sangat Baik \\
\hline & Jumlah Skor & 9,15 & Sangat Baik \\
\hline & Rerata Skor & $\mathbf{4 , 5 8}$ & \\
\hline
\end{tabular}

Hasil dari tabel di atas, menunjukkan bahwa hasil evaluasi dari kualitas mendapatkan nilai rerata skor 4,58 untuk aspek isi mendapatkan nilai rerata skor 4,57. Sehingga jumlah akhir untuk rerata skor dari semua aspek yang telah dinilai oleh responden pada uji coba pemakaian pada kelompok besar yaitu 4,58 dimana nilai tersebut termasuk ke dalam kategori sangat baik.

(9) Revisi hasil uji coba pemakaian pada kelompok besar

Berdasarkan hasil uji coba pemakaian pada kelompok besar, menunjukkan hasil sangat baik dari setiap aspeknya. Beberapa dari ibu hamil memberikan saran bahwa media audio visual persiapan persalinan sudah bagus. Maka dari itu, dalam tahap uji coba pemakaian pada kelompok besar tidak ada revisi.

\section{PEMBAHASAN}

Berdasarkan hasil penelitian dan pengembangan tentang kelayakan rancangan media audio visual persiapan persalinan sebagai media promosi kesehatan pada ibu hamil, penilaian yang dilakukan ahli media yaitu skor 4,5 untuk aspek visible, skor 5 untuk interesting, skor 3,67 untuk simpel, skor 5 untuk useful, skor 4,28 accurate, skor 4,5 untuk legitimate dan skor 5 untuk structure, Dari semua aspek dapat disimpulkan rerata skor 4,56 dan termasuk ke dalam kategori sangat baik. Penilaian oleh ahli materi, skor 5 untuk aspek kebenaran, keluasan dan kedalaman materi, skor 4,5 untuk aspek bahasa, skor 4,3 untuk aspek keterlaksanaan, skor 4,6 untuk aspek tampilan video, dan yang terakhir untuk aspek audio mendapat skor 5 . Dari semua aspek dapat disimpulkan rerata skor 4,68 dan termasuk ke dalam kategori sangat 
baik. Dilihat dari hasil yang diperoleh untuk setiap aspek, maka aspek tersebut termasuk ke dalam kategori sangat baik, hal tersebut sesuai dengan kriteria penilaian menurut Eko PW (2013) dalam Atiko (2019) yaitu hasil $X>4,2=$ Sangat baik, hasil $3,4<x \leq 4,2=$ Baik, hasil 2,6 $<x \leq 3,4=$ Cukup Baik, hasil 1,8 $<x \leq 2,6=$ Tidak Baik, hasil $x \leq 1,8=$ Sangat Tidak Baik. ${ }^{26}$

Dari hasil validasi yang telah dilakukan oleh ahli media, ahli materi dan responden dari kelompok kecil dan kelompok besar yang mendapatkan nilai rerata skor dari setiap penilaian yaitu skor 4,56 untuk ahli media, skor 4,68 untuk ahli materi, skor 4,4 untuk responden kelompok kecil dengan dan skor 4,58 untuk responden kelompok besar, sehingga dapat disimpulkan bahwa kelayakan rancangan media audio visual persiapan persalinan sebagai media promosi kesehatan pada ibu hamil dapat dikategorikan sangat baik, dimana hal tersebut juga dapat dikategorikan sangat layak digunakan sebagai media promosi kesehatan.

Ummyssalam (2017) dan Mubarak (2011) telah membahas mengenai keuntungan dan kelebihan dari penggunaan media audio visual, tetapi media audio visual juga mempunyai kekurangan, salah satunya yaitu menurut Husmiati (2010), bahwa kelemahan media audio visual salah satunya film yaitu memerlukan tempat dan waktu, pembuatannya memerlukan biaya yang mahal dan sangat tergantung secara teknis pada listrik dan berbagai alat terkait, tidak dapat menggambarkan realitas yang sebenarnya, tidak mampu mengontrol pikiran dan pengetahuan responden selama menonton, sehingga perlu melakukan diskusi setelah selesai menonton media audio visual tersebut. ${ }^{30}$

Berdasarkan dari kegiatan selama melakukan penelitian, terdapat beberapa hambatan penggunaan media audio visual yaitu selama penelitian peneliti harus mengumpulkan ibu hamil dari setiap desa dan harus dengan bantuan dari kader dan bidan desa, pada saat kegiatan peneliti harus membawa infokus, laptop serta speaker untuk penunjang dalam melakukan promosi kesehatan sehingga menyebabkan peneliti kesusahan pada saat akan menuju ke tempat penelitian yang diharuskan membawa banyak peralatan.

Hal tersebut sesuai dengan hasil penelitian Ariwibowo dan Parmin (2015), bahwa meskipun penggunaan media audio visual sudah mendapat respon yang baik dari responden dalam skala kecil dan besar dan media sangat layak digunakan, namun penggunaan media audio visual mengharuskan tersedianya alat-alat yang cukup 
banyak seperti proyektor, LCD dan laptop untuk dapat menggunakan media audio visual dengan baik dan lebih untuk menggunakan media audio visual dalam pembelajaran. ${ }^{31}$ Tetapi, terlepas dari itu semua, media audio visual lebih banyak kelebihan dibandingkan dengan kelemahannya. ${ }^{30}$

Berdasarkan hasil penelitian Fitatul (2017), terdapat pengaruh pemberian promosi kesehatan antara media video dengan leaflet terhadap pengetahuan remaja tentang pernikahan dini yaitu terjadi peningkatan 20,45\% pada video dan 13,47\% pada leflet. Peningkatan sikap remaja tentang pernikahan dini yaitu 14,28\% pada video dan 11,03\% pada leaflet terjadi peningkatan pengetahuan dan sikap remaja yang bermakna pada ke 2 kelompok, tetapi peningkatan video lebih tinggi dari leaflet, sehingga dapat disimpulkan bahwa penggunaan media video lebih efektif dalam promosi kesehatan. ${ }^{33}$

Menurut Machfoedz (2009) dalam Khatarina T, dan Yuliana (2017), bahwa panca indera yang paling banyak menyalurkan pengetahuan ke otak adalah mata (kurang lebih 75\%-87\%), sedangkan 13-25\% pengetahuan manusia diperoleh atau disalurkan melalui indera lainnya, sehingga semakin banyak panca indera yang digunakan maka semakin jelas pengetahuan yang diperoleh. Media audio visual merupakan salah satu media yang menyajikan informasi atau pesan melalui indera pendengaran dan penglihatan. ${ }^{34}$

Penggunaan media audio visual dapat menunjang promosi kesehatan karena media merupakan alat peraga yang digunakan dalam rangka atau bertujuan untuk kemudahan dalam menyampaikan pesan. Alat peraga disusun berdasarkan prinsip bahwa pengetahuan yang ada pada manusia diterima atau ditangkap melalui panca indera. ${ }^{34}$

Maka dari itu, dengan dibuatnya media audio visual tentang persiapan persalinan melalui beberapa tahapan, kemudian menghasilkan produk akhir sebuah video dan telah mendapatkan uji validitas dengan kategori layak dan dapat digunakan sebagai bahan penunjang dalam kegiatan promosi kesehatan.

\section{SIMPULAN}

Berdasarkan hasil dari penelitian dan pengembangan mengenai rancangan media audio visual persiapan persalinan sebagai media promosi kesehatan pada ibu hamil, maka dapat ditarik simpulan sebagai berikut: 
1. Rancangan media audio visual telah selesai dibuat, durasi dari rancangan media audio visual yang berupa video yaitu 3 menit 38 detik dengan judul "Persiapan persalinan".

2. Pengembangan dari rancangan media audio visual telah dilakukan melalui beberapa tahapan, yaitu potensi masalah dan telaah kebutuhan, mengumpulkan data, desain produk, validasi desain, revisi desain, uji coba produk, revisi produk, uji coba pemakaian dan revisi produk.

3. Kelayakan dari rancangan media audio visual telah di validasi dan mendapatkan nilai rerata skor dari setiap penilaian yaitu rerata skor 4,56 oleh ahli media termasuk ke dalam kategori sangat baik, rerata skor 4,68 oleh ahli materi termasuk ke dalam kategori sangat baik dan rerata skor 4,4 oleh responden kelompok kecil dan rerata skor 4,58 oleh responden kelompok besar termasuk ke dalam kategori sangat baik. Dapat disimpulkan bahwa hasil dari validasi oleh ahli media, ahli materi, responden kelompok kecil dan kelompok besar terhadap media audio visual persiapan persalinan mendapatkan kategori sangat baik dan termasuk sangat layak sebagai media promosi kesehatan pada ibu hamil di wilayah kerja UPT Puskesmas Ciawi tahun 2019.

\section{DAFTAR PUSTAKA}

1 Profil Kesehatan Indonesia. Kementerian Kesehatan Republik Indonesia;2018. HIm. 118-123.

2 Profil Kesehatan Provinsi Jawa Barat;2017.

3 Romauli, Suryati. Buku Ajar askeb 1: Konsep Dasar Asuhan Kehamilan. Yogyakarta: Nuha Medika; 2011. HIm. 146.

4 Survei Demografi dan Kesehatan Indonesia; 2017.

5 Dinas kesehatan Provinsi NTB;2013. Dalam: Shammakh, A, Pengetahuan Persiapan Persalinan Ibu Primigravida Trimester III di Wilayah Kerja Puskesmas Gunung Sari. 2016; 4(2).

6 Mubarak, W.I. Promosi Kesehatan untuk Kebidanan. Jakarta: Salemba Medika; 2011. HIm. 5-119.

7 Ummyssalam, A.T.A. Kurikulum Bahan dan Media Pembelajaran PLS. Yogyakarta: Deepublish; 2017. HIm. 51. 
8 Ahmadi F, Ibda H. Media Literasi Sekolah: Teori dan Praktik. Semarang: Pilar Nusantara; 2018. HIm. 275.

9 Lisa L. Pengaruh Pendidikan Kesehatan dengan Audio Visual tentang HIV/AIDS terhadap Pengetahuan dan Sikap Remaja kelas X SMK Negeri 1 Bantul. Yogyakarta: Jenjang Diploma IV Sekolah Tinggi IImu Kesehatan Aisyiyah Yogyakarta; 2015.

10 Agustin W,P. Pengaruh Pemberian Penyuluhan dengan Media Video dan Booklet terhadap tingkat Pengetahuan Kesehatan Reproduksi Remaja di SMK 2 Muhammadiyah Bantul. Yogyakarta: Prodi Sarjana Terapan Kebidanan Jurusan Kebidanan Poltekes Kemenkes Yogyakarta; 2018.

11 Muhammad AH. Uji Kelayakan Media Audio Visual berupa Video Klip "Cegah HIVAIDS" sebagai Media Promosi Kesehatan. Jember: Bagian Promosi Kesehatan dan Ilmu Perilaku Fakultas Kesehatan Universitas Jember; 2019.

12 Nurjannah H. Pengembangan Media Pembelajaran berbasis Audio Visual pada Materi Pencemaran Lingkungan kelas VII SMP Negeri 6 Duampanua Kabupaten Pinrang. Makassar: fakultas Tarbiyah dan Keguruan Universitas Islam Negeri Alauddin Makassar; 2017.

13 Fuji L. Pengembangan Media Audio Visual dalam Pembelajaran Budaya Hidup Sehat Khususnya kebersihan Tangan dan Kaki pada Peserta Didik Kelas II SD Negeri Semen Kecamatan Windusari. Yogyakarta: Pendidikan Guru Sekolah Dasar Pendidikan Jasmani Jurusan Pendidikan Olahraga Fakultas IImu Keolahragaan Universitas Yogyakarta; 2017.

14 Tafakur K. Pengembangan dan Uji Kelayakan Modul pembelajaran Microsoft Access 2010 sebagai Bahan Ajar Keterampilan Komputer dan Pengelolaan Informasi untuk Kelas XI SMK Negeri Bansari. 2015.

15 Matterson. Tingkat Pengetahuan Ibu Hamil Primigravida Trimerter III dengan Persiapan Ibu Hamil dalam menghadapi Persalinan. \{diunduh 18 Oktober 2019\}. Tersedia dari: http://digilib.unimus.ac.id/files/disk1/108/itptunimus-gdlmochamadhe-5400-3-bab2.pdf

16 DepKes Rl;2008. Dalam: Jumiati RD. Pengaruh Konseling terhadap Persiapan Persalinan. Purwokerto: Fakultas IImu Kesehatan UMP; 2012. HIm.15

17 Jumiati RD. Pengaruh Konseling terhadap Persiapan Persalinan. Purwokerto: Fakultas IImu Kesehatan UMP; 2012. 
18 Ira, Jayanti. Evidence Based dalam Praktik Kebidanan. Yogyakarta: Deepublish; 2019. HIm. 26-27.

19 DepKes Rl; 2010. Dalam: Damai, Yanti. Konsep dasar Asuhan Kehamilan. Bandung: PT Refika Aditama; 2017. HIm. 137.

20Rohmatin H, dkk. Mencagah Kematian Neonatal dengan P4K. Malang: Unidha Press; 2018.

21 Masturoh I, anggita N. Bahan Ajar Rekam Medis dan Informasi Kesehatan (RMIK): Metodologi Kesehatan. Kementerian Kesehatan Rl; 2018. HIm. 125.

22 Sugiyono. Metode penelitian Kuantitatif, Kualitatif dan R\&D. Bandung: Alfabeta; 2017. HIm. 80-297.

23 Prihanti GS. Pengantar Biostatistik. Malang: Universitas Muhammadiyah malang; 2016. HIm. 9.

24 Setyosari; 20. Dalam: Eneng WN. Kelayakan Buku Saku Konsumsi Tablet FE Bagi Ibu Hamil di Wilayah Kerja Puskesmas Sangkali. Politeknik kesehatan Tasikmalaya Jurusan Kebidanan; 2019.

25 Surakhmad; 1994. HIm. 100. Dalam: Unaradjan DD. Metode Penelitian Kuantitatif. Jakarta: Universitas Katolik Indonesia Atma Jaya; 2019. hlm. 124.

26Eko PW; 2013. Hlm. 238. Dalam: Atiko. Bokleet,Brosur, dan Poster sebagai Karya Inovatif di Kelas. Gresik: Caramedia Communication; 2019. HIm 57.

27 Hidayat E.W., dan Irawan E.P; 2013. Dalam: Eka W.H,. Andi N.R., Muhammad F.A. Penerapan Finite State Machine pada Battle Game Berbasis Augmented Reality. JEPIN (Jurnal Edukasi dan Penelitian Informatika). 2019; 5(1): 59-60.

28 Sholichah M.W. Pengembangan Media Pembelajaran Video Stop Motion pada

Pelajaran Dasar-Dasar Desain Kriya Kelas X Sekolah Menengah Kejuruan. Yogyakarta: Program Studi Pendidikan Kriya Jurusan Pendidikan Seni Rupa Fakultas Bahasa dan Seni Universitas Negeri Yogyakarta; 2018.

29 Shammakh, A. Pengetahuan Persiapan Persalinan Ibu Primigravida Trimester III di Wilayah Kerja Puskesmas Gunung Sari. 2016.

30 Husmiati R. Kelebihan dan Kelemahan Media Film sebagai Media Pembelajaran Sejarah (Survei pendapat Mahasiswa di Jurusan Sejarah Sejarah FIS-UNJ). Jurnal Sejarah lontar. 2010; 7(2).

31 Ariwibowo P., dan Parmin. Pengembangan Audio Visual Sistem Sirkulasi darah yang berpendekatan Saintifik. Unnes science Education Jurnal. 2015; 4(2). 


\section{ARIABI}

32Dermawan dan Setiawati; 2008. Dalam: Yulistasari, Yessy, dkk. Efektivitas Pendidikan Kesehatan Menggunakan Media Audio Visual terhadap Perilaku Personal Hygiene (Genetalia) Remaja Putri dalam Mencegah Keputihan. Riau: Program Studi ilmu Keperawatan Universitas Riau. 2013.

33 Fitatul I. Pengaruh Promosi Kesehatan dengan Video dalam meningkatkan Pengetahuan dan Sikap Remaja tentang Pernikahan Dini di SMP Negeri 2 Sanden Bantul. Yogyakarta: Program Studi Bidan Pendidik Jenjang Diploma IV Fakultas Ilmu Kesehatan Universitas Aisyiyah. 2017.

34Khatarina T., dan Yuliana. Pengaruh Penyuluhan Kesehatan Reproduksi Melalui Audio Visual dengan Hasil Pengetahuan setelah Penyuluhan pada Remaja SMA Negeri 2 Pontianak. (Jurnal Kebidanan). 2017; 7(1): 49-50. 